ISSN 0258-7122

Bangladesh J. Agril. Res. 37(2): 307-325, June 2012

\title{
ADOPTION AND DIFFUSION OF POWER TILLERS IN BANGLADESH
}

\author{
M. A. QUAYUM ${ }^{1}$ AND AMin MUHAMMAD Ali ${ }^{2}$
}

\begin{abstract}
The present study examines the extent of adoption of power tillers (PT) in Bangladesh and analyzes the variation in adoption across regions and across farms in selected areas to investigate the justification for wider use of power tillers. Primary and secondary data were used. Primary data were collected from 267 sample farmers from eight villages of four upazilas of four districts using proportionately stratified random sampling technique. Secondary data were collected from different published sources. The average growth rate of power tillers in Bangladesh was 21.0 percent during 1993-2003. Power tillers are unevenly distributed all over the country. The highest and the lowest adoption of power tillers were 44.4 and 3.6 percent in Rajshahi and Barisal divisions respectively. The percentage of area cultivated under power tiller is 69.6. Multiple regression analysis indicates that there is a significant relationship between number of PT and credit availability. The credit availability may be a decisive factor in increasing cropping intensity which requires reduction of turnaround time. Irrigated area, number of small farm holdings and credit availability are found to have significant and positive association with intensity of power tiller use in different regions of Bangladesh. Analysis of Logit Model applied to farm level data indicates that the educational level and income surplus of farmers have significant positive relationship with ownership of power tillers. The coefficients of adult family members and number of draught power owned by the farmers are however found to be significantly negative. The number of power tiller is increasing with the decreasing of draught animal power. Thus credit should be provided to the farmers and owners of all regions of the country to buy power tillers to adopt evenly to increase crop production profitably.
\end{abstract}

Key words: Diffusion, power tillers, growth rate, distribution, credit availability.

\section{Introduction}

Agriculture plays an important role in the economy of Bangladesh. This sector contributes at present about $20 \%$ of the total gross domestic product (GDP) of Bangladesh. Crop sub sector alone contributes about $11 \%$ of the total GDP of the country and about $75 \%$ of the agricultural GDP (GOB, 2011). In the late 1990s, rice production alone accounted for about $55 \%$ of the persons employed in the crop sub-sector (Nasiruddin, 1997). About $44 \%$ of the total labour force of Bangladesh was employed in agricultural sector during 2009-10 (GOB, 2011).

\footnotetext{
${ }^{1 \& 2}$ Senior Scientific Officer, Bangladesh Rice Research Institute (BRRI), Gazipur and Professor, Department of Economics, respectively, Jahangirnagar University, Savar, Dhaka, Bangladesh.
} 
Therefore, the performance of the economy of Bangladesh in terms of output and employment still largely depends on the agricultural sector.

Since 1980s, the net cultivable area and net sown area of Bangladesh have been decreasing due to rapid industrialization and urbanization (housing, road construction, etc.) and at the same time food requirement is rapidly increasing. Non-agricultural sector is engulfing 220 ha of good quality arable lands per day (Karim, 2009). The absolute net cropped area decreased from 8.56 million ha in 1980-81 to 7.97 million ha in 2004-05 (MoA, 2007). It is extremely difficult to expand land area horizontally. At present per capita cultivated area and operated area are 0.05 ha and 0.07 ha, respectively (BBS, 2006). Shrinkage of area may also affect the total food availability. Crop production must be increased to feed the growing population and save foreign exchange. Therefore, it is necessary to increase productivity of land and cropping intensity and grow high yielding varieties (HYV) of crops improving cropping patterns with cost effective technologies like power tillers. But in Bangladesh average farm size is quite small (0.62 ha in 2011) (Krishi dairy, 2011) and plots owned or operated by an average farm is very small and scattered. Large- scale operation is necessary to reap benefit from such devices.

Power tiller is introduced in Bangladesh for land preparation, but now it is used for different purposes, such as transportation (land and river), irrigation, paddy threshing, milling rice, and spices, etc. Farmers may use these technologies simply by seeing others. Power tiller may be used for different purposes depending on environment, ability of farmers for buying attachments and availability of credit facilities. Therefore, PT can be used round the year and increase profit and employment. In order to measure the benefit from PT all these activities should also be considered. Such benefits may have positive implication for wide adoption of power tillers.

A few researchers studied adoption and extension of PT using secondary data. They did not collect data for PT adoption at farmers' level all over the country. So it is important to estimate the number of power tillers and adoption as well as diffusion at the regional and national level. Before examining the factors affecting PT use the ownership should be examined. If in an area none owns a PT then probably nobody in the area will be able to use it. It is very difficult for farmers to purchase PT due to financial problem. So in Bangladesh context issues of ownership of PT and factors affecting ownership of PT must be examined.

This study is an attempt to examine the wider use of PTs and assess the extent of adoption of power tillers in Bangladesh to improve the lot of the users and owners and farm workers. 
The use of PT is not evenly spread all over Bangladesh. The differential rates of adoption of PT across regions within a country may give rise to interregional disparity of income, employment which may lead to social discontent. The analysis of differential rates of adoption for PT may help us to understand the relationship between the characteristics of PT and its diffusion, and provide guidelines for the research about the land preparation for crop production. Kim (1972) in Japan reported that number of draught power is insignificantly associated with the introduction of PTs.

Socio-political power and farm size were major determinants of acquisition of power tillers (Bhuiyan, 1981). Big farmers and influential persons in the society who are very close to the politicians and government personnel can acquire PT more easily. Asaduzzaman (1988) estimated a total of 2500 power tillers and tractors (67 \% power tillers and 33\% tractors) existed during 1985. Both PTs and tractors were found to be concentrated in a few districts. Number of tractors decreased by $60.3 \%$ from 1977 to $1983-84$ while that of power tillers increased by 11.7 percent during the same period in Bangladesh (Abeden, 1995). In 1984 and 1996 the number of power tillers were 18000 (Sattar et al., 1993) and 66880 (BBS, 1996) respectively. However, the number of PTs in Bangladesh in 2006 was 236048 (Quayum, 2009).

There is a positive relationship between farm size and number of PTs (Gill, 1981; Jaim and Rahman, 1999). There is also a positive relationship between education and adoption of PTs and a negative relationship between number of draught animals and adoption of PTs. There was a close positive relationship between power tiller ownership and the educational background of the farm households (Alam, 1995; Jaim and Rahman, 1999). In contrast Barton (2000) found that PTs are widely adopted and used by all sizes of farms in Tangail and Mymensingh areas. PTs are, therefore, not only used by big farmers as Gill (1981) mentioned in his report.

The density of livestock and that of PT coexist. There is a negative relationship between farm size and adoption of PTs. The coefficients of the variables representing the extent of presence of small- holdings and landless holdings are positive and statistically significant (Rahman, 2002). If the Land owners find tilling of land by power tiller is more profitable and less costly than that of DAP they would use power tillers rather than DAP. The extent of power tiller use is positively associated with favourable physical environment and irrigation (Dey, 2006). The non-availability of DAP may be a reason for adopting PT.

Therefore, PT can be used round the year and increase profit and employment. In order to measure the benefit from PT, all these activities should also be considered. Such benefits may have positive implication for wide adoption of power tillers. This study is an attempt to examine the process of 
transfer and wide use of PTs. There is no study dealing with the process of transfer of power tiller technology in Bangladesh. It is important to know about the process for framing a guideline for future transfer of technology. Earlier studies enquired about the impact of power tiller on output and employment. Such studies were based on surveys done in limited areas with small sample size. On the results of such studies a conclusion can not be drawn for the country as a whole. So a study with more areas and bigger samples should be done to examine the diffusion of PT and to draw a conclusion on the basis of the findings of the present study.

\section{Specific Objectives of the Study}

The general aim of this study is to investigate the justification for wider use of power tillers in Bangladesh. The present study examines the extent of adoption of power tillers in Bangladesh and analyzes the variation in adoption across regions and across farms in selected areas:

(1) to deteremine the growth of power tillers adoption in Bangladesh;

(2) to analyze the diffusion of power tiller technology at regional and national level in Bangladesh agriculture; and

(3) to know the reasons of purchasing power tillers by the farmers.

\section{Methodology}

\section{Sampling procedure and data collection}

Four upazilas, namely Chandina, Nandigram, Chuadanga sadar, and Singair were randomly selected from Comilla, Bogra, Chuadanga, and Manikgonj districts of Bangladesh, respectively. Two villages were randomly selected from one agricultural block of the selected upazilas. Selected villages were Rushulpur and Lona of Chandina, Nandigram and Chakalma of Nandigram, Shangkarchandra and Manikdihi of Chuadanga sadar, and Luxmipur and Beguntahary of Singair. A sample frame was developed from the comprehensive farmers list of Department of Agriculture Extension (DAE) for each village. Sample farmers were stratified into four stratum by the help of DAE and key informant farmers of the respective villages. Stratum were (i) PT owner farmers (those who both own and use PT), (ii) PT hirer- user farmers (those who hire and use PT), (iii) draught animal power owner farmers (those who both own and use DAP) and (iv) draught animal power hirer- user farmers (those who hire and use DAP). Farmers those who used both power tiller and draught animal power in the same plot for land preparation were identified and not considered as sample. Stratified random sampling technique was followed for selecting sample farms proportionately from each stratum. Structure questionnaires were used for collecting data from the farmers of the developed stratum (e.g, PT owner- users, 
PT hirer- users, bullock power owner- users, and bullock power hirer-users). Sample size was 267. Among those 180 were power tiller users (41 PT owners and 139 PT hirers) and 87 were bullock power users (58 DAP owners and 29 DAP hirers) shown in Table 1. Survey was done during April 2003 to December 2003.

Table 1. Distribution of sample farmers in the selected villages.

\begin{tabular}{|c|c|c|c|c|c|c|c|}
\hline Location & $\begin{array}{c}\text { PT } \\
\text { owner- } \\
\text { users }\end{array}$ & $\begin{array}{l}\text { PT } \\
\text { hirer- } \\
\text { users }\end{array}$ & $\begin{array}{c}\text { PT } \\
\text { users }\end{array}$ & $\begin{array}{l}\text { DAP } \\
\text { owner- } \\
\text { users }\end{array}$ & $\begin{array}{l}\text { DAP } \\
\text { hirer- } \\
\text { users }\end{array}$ & $\begin{array}{l}\text { DAP } \\
\text { users }\end{array}$ & Total \\
\hline $\begin{array}{l}\text { Chandina (Rashulpur \& } \\
\text { Lona), Comilla }\end{array}$ & 7 & 33 & 40 & 8 & 5 & 13 & 53 \\
\hline $\begin{array}{l}\text { Nandigram (Nandigram } \\
\text { \& Chakalma), Bogra }\end{array}$ & 18 & 37 & 55 & 21 & 7 & 28 & 83 \\
\hline $\begin{array}{l}\text { Chuadanga sadar } \\
\text { (Sangkarchandra \& } \\
\text { Manikdihi), Chuadanga }\end{array}$ & 8 & 38 & 46 & 16 & 9 & 25 & 71 \\
\hline $\begin{array}{l}\text { Singair (Luxmipur \& } \\
\text { Beguntahary), } \\
\text { Manikgonj }\end{array}$ & 8 & 31 & 39 & 13 & 8 & 21 & 60 \\
\hline All/total & 41 & 139 & 180 & 58 & 29 & 87 & 267 \\
\hline
\end{tabular}

\section{Analytical technique of growth of power tillers and their adoption}

Adoption of power tillers may be defined in various ways. Adoption by a division (an administrative unit) within a country may be defined as (i) proportion of power tillers in a division to total number of power tillers in the country (ii) proportion of farms in the division owning power tillers, (iii) number of power tillers per 1000 persons in the division, (iv) number of power tillers per thousand hectare of (a) irrigated area, (b) gross cropped area, (c) net sown area, and (d) total land area in each division. Similar indicators can be used for divisions (Each division is comprised a few districts). There are at present 6 divisions in Bangladesh.

At present, power tillers are widely used by the farmers in Bangladesh but the exact number of PT in operation in different divisions and smaller administrative units of Bangladesh is not known. However, an attempt was made to find out the current actual number of power tillers used all over the country. With this view, a survey was made and information regarding number of power tillers in 1993 and during the period 1998 to 2003 was collected by Sub Assistant Agricultural Officers (Ex Block Supervisors) for each agricultural block. This information was then sent to the author through Deputy Director of the Department of Agricultural Extension. Other related information was collected from different published reports and Bangladesh Bureau of Statistics. 
In addition, it is necessary to examine the relationship between number of PT and cultivated land, population, agricultural household, irrigated area, cropped area at regional and national level and to find out the major factors affecting mechanization of cultivation.

Semi-log model was used to analyze the growth rate of number of PT with the available data collected from different sources. The model is In $\mathrm{Y}_{\mathrm{t}}=$ $\mathrm{B}_{1}+\mathrm{B}_{2} \mathrm{t}+\mathrm{ut}$ (Gujarati, 1998), where, $\mathrm{Y}=$ number of $\mathrm{PT}$ and $\mathrm{t}=$ time period, $\mathrm{u}=$ disturbance term. The number of power tillers in the divisions and density of power tillers in Bangladesh in relation to land area were analyzed and disscused. To find out the factors associated closely with the introduction of power tillers in Bangladesh, multiple regression analysis was done by using various explanatory variables.

\section{Analysis of district level variation in adoption of PTs}

In order to find out the factors associated with the introduction of power tillers in Bangladesh, multiple regression analysis was done. Number of power tillers owned by farmers per net cropped area in hectares in the division (Y) was the dependent variable.

The explanatory variables or factors that are used in the analysis are number of cattle and buffaloes per ha of net cropped area (NCA), $\mathrm{X}_{1}$, number of small farm holdings per ha of NCA, $\mathrm{X}_{2}$, number of landless holdings per ha of NCA, $\mathrm{X}_{3}$, total irrigated area per ha of NCA, $\mathrm{X}_{4}$, population per ha of NCA, $\mathrm{X}_{5}$, credit availability per ha of NCA, $X_{6}$, wage rate (Taka/day), $X_{7}$ and relative cost of cultivation (cost of cultivation by PT divided by cost of cultivation by DAP), $\mathrm{X}_{8}$. The equation is the simplest form of all the equations. The following model is used for analysis:

$$
\begin{gathered}
Y_{j}=e^{\left(\alpha X_{1} \beta^{1} X_{2} \beta^{2} X_{3} \beta^{3} X_{4} \beta^{4} X_{5} \beta^{5} X_{6} \beta^{6} X_{7} \beta^{7} X_{8} \beta^{8} U_{j}\right)} \\
Y_{j}=\alpha \coprod_{i=1}^{8} X_{i}{ }^{\beta} e^{u i}
\end{gathered}
$$

Equation (3) can be transformed by taking natural log of both sides of the equation as:

$\operatorname{In} Y=\operatorname{In} \alpha+\beta_{1} \operatorname{In} X_{1}+\beta_{2} \operatorname{In} X_{2}+\beta_{3} \operatorname{In} X_{3}+\beta_{4} \operatorname{In} X_{4} \ldots \ldots+\beta_{n} \operatorname{In} X_{n}+U$

\section{Analysis of ownership of power tiller at the farm level}

Adoption of power tillers and relationship with some other factors at farm level have been analyzed and discussed. There may be many factors which can affect the ownership of power tillers. So, it is important to examine the factors affecting the ownership of power tiller at the farm level. 
An attempt has been made to explain ownership of power tiller at farm level which is a dependent variable $(0,1)$. The factors that are believed to determine ownership of PT at farm level are identified. These factors are:

$\mathrm{X}_{1}=$ age of the farmer,

$\mathrm{X}_{2}=$ educational level of the farmer (years of schooling,

$\mathrm{X}_{3}=$ number of adult family members of the household,

$\mathrm{X}_{4}=$ farm size of the sample farmer in ha,

$\mathrm{X}_{5}=$ number of draught power owned by the farmer) and

$\mathrm{X}_{6}=$ level of surplus income of the household per year (Taka).

In order to assess the impact of the factors in case of ownership of power tiller at the farm level, a regression model has been used.

The regression model that has been used contains a dependent variable which is dichotomous in nature, taking 1 or 0 value, where 1 means the ownership of PT and 0 means non ownership of PT. That is, a farmer either owns a power tiller or he does not own.

Logit model or Probit model can be used. Logit model is better in estimating the explanatory variables because this model guarantees that the estimated probabilities will indeed lie between the logical limits 0 and 1 . So logit model was used in this study.

$$
\begin{aligned}
& e^{B X} \\
& \text { Now let, } \quad \mathrm{Y}= \\
& 1+\mathrm{e}^{\mathrm{BX}}
\end{aligned}
$$

where, $\mathrm{Y}=0,1$

$$
\text { and } \mathrm{BX}=\mathrm{B}_{0}+\mathrm{B}_{1} \mathrm{X}_{1}+\mathrm{B}_{2} \mathrm{X}_{2}+\ldots \ldots \ldots+\mathrm{B}_{\mathrm{n}} \mathrm{X}_{\mathrm{n}}
$$

(BX is a shorthand expression in matrix form for the expression $\mathrm{B}_{0}+\mathrm{B}_{1} \mathrm{X}_{1}+$

$\left.\mathrm{B}_{2} \mathrm{X}_{2}+\ldots \ldots \ldots+\mathrm{B}_{\mathrm{n}} \mathrm{X}_{\mathrm{n}}\right)$

$$
\mathrm{Y}=\mathrm{e}^{\mathrm{BX}} \text { and }(1-\mathrm{Y})=1-\mathrm{e}^{\mathrm{BX}}
$$

Assuming $\mathrm{Yi}=$ probability of owning $\mathrm{PT}$ at the farm level (ith farm level) $(0<$ $\mathrm{Yi}<1)$

Then,

$$
\frac{Y_{i}}{1-Y_{i}}
$$


is the measure of "odd ratio" of having the outcome that is $\mathrm{Yi} /(1-\mathrm{Yi})$ is simply the odd ratio in favour of owning a PT- the ratio of the probability that a farm will own a PT to the probability that it will not own a PT; then the $\log _{\mathrm{e}}$ of odd on the "logit"

can be written as

$$
\ln \left(\frac{Y_{i}}{1-Y_{i}}\right) \text { ( taking the natural log) }
$$

$\mathrm{Yi}$

Below we show that $\ln \left[\frac{Y_{i}}{1-Y_{i}}=\frac{\frac{e^{B X}}{1+e^{B X}}}{1-\frac{e^{B X}}{1+e^{B X}}}=\frac{e^{B X} /\left(1+e^{B X}\right)}{\left(1+e^{B X}-e^{B X} / 1+e^{B X}\right.}=e^{B X}\right]$

$$
1-Y i
$$

Therefore, $\quad \ln \frac{Y_{i}}{1-Y_{i}}=B X$

that is $\mathrm{Y}$, the $\log$ of the odds ratio, is not only linear in $\mathrm{X}$, but also ( from the estimation viewpoint) linear in the parameters. $\mathrm{Y}$ is called the logit. Now the equation can be written by incorporating error terms and using relevant explanatory variables as

Yi

ln --- $=\mathrm{B}_{0}+\mathrm{B}_{1} \mathrm{X}_{1}+\mathrm{B}_{2} \mathrm{X}_{2}+\mathrm{B}_{3} \mathrm{X}_{3}+\mathrm{B}_{4} \mathrm{X}_{4}+\mathrm{B}_{5} \mathrm{X}_{5}+\mathrm{B}_{6} \mathrm{X}_{6}+\mathrm{ui}$

$$
1--Y i
$$

Where, $\mathrm{Y}=$ Ownership of power tiller.

$\mathrm{B}_{0}=$ constant;

$\mathrm{B}_{1} \ldots \ldots \mathrm{B}_{6}$ are coefficients. Since we have six explanatory variables.

$\mathrm{ui}=$ error term

\section{Results and Discussion}

\section{Adoption status and growth rate of power tiller use}

The number of power tillers and growth rate of power tiller use in different divisions of Bangladesh are shown in Table 2. The rate of increase in the use of power tillers during 1993-2003 is found to be highest in Dhaka division and the lowest in Chittagong division and the corresponding figures for rate of increase are $415 \%$ and $245 \%$, respectively. It should be noted that Rajshahi division, 
though achieved a moderate growth rate (about 20.7\%) had relatively very high number of power tillers in 1993 (14034 as against 6111 for Dhaka division and nearly half the total number of the power tillers in Bangladesh in 1993). However, during 1993-2003 the number of power tillers has increased in Bangladesh by $338 \%$.

Table 2. Number and annual growth of power tillers in Bangladesh.

\begin{tabular}{|c|c|c|c|c|c|c|c|c|c|}
\hline \multirow[b]{2}{*}{ Divisions } & \multicolumn{7}{|c|}{ Year } & \multirow{2}{*}{ 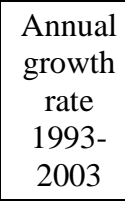 } & \multirow{2}{*}{\begin{tabular}{|c} 
Increas \\
e from \\
1993 to \\
2003 \\
$(\%)$
\end{tabular}} \\
\hline & 1993 & 1998 & 1999 & 2000 & 2001 & 2002 & 2003 & & \\
\hline Barisal & 1091 & 2272 & 2699 & 3140 & 3566 & 4008 & 4822 & 21.0 & 342 \\
\hline Chittagong & 3359 & 6626 & 7115 & 7841 & 9036 & 9916 & 11595 & 17.0 & 245 \\
\hline Rajshahi & 14034 & 27591 & 31875 & 37228 & 43081 & 49858 & 59123 & 20.7 & 321 \\
\hline Dhaka & 6111 & 13827 & 15836 & 18514 & 21745 & 25598 & 31471 & 23.1 & 415 \\
\hline Khulna & 4338 & 9710 & 11280 & 12832 & 14999 & 17298 & 21059 & 22.1 & 385 \\
\hline Sylhet & 1466 & 2657 & 2981 & 3329 & 3670 & 4275 & 5173 & 17.6 & 253 \\
\hline Bangladesh & 30399 & 62683 & 71786 & 82884 & 96097 & 110953 & 133243 & 21.0 & 338 \\
\hline
\end{tabular}

Note: (1) Using this formula In $Y_{t}=B_{1}+B_{2} t+u_{t}$, where $Y=$ Number of power tillers, $t=$ time period, $\mathrm{B}_{1}=$ coefficient,

$$
\mathrm{B}_{2}=\text { growth rate multiplying by } 100 \text {. }
$$

(2) Growth rate in last column = (No. of PT in 2003- no. of PT in 1993) divided by no. of PT in 1993 multiplied by100.

The division-wise annual growth rate is calculated for the period 1993 to 2003 and it is found that the highest growth rate is achieved by Dhaka division among all the divisions in Bangladesh and the lowest in Chittagong division and these figures were 23.1 and 17.0 percent respectively. The average growth rate of power tillers in Bangladesh was found to be 21.0 percent during 1993-2003.

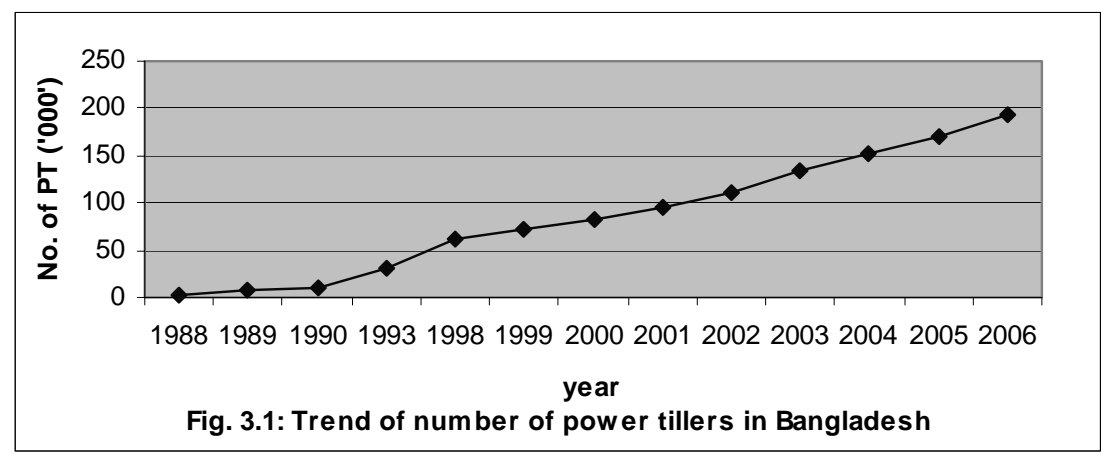

Source: Alam et al., 2004 and Field survey, 2003. 
Figure 1 shows actual number of PTs during 1988-2003. Figures for the period 2004-2006 are obtained by using the growth rate of number of power tillers that prevailed during 1988-2003. This suggests that in reality the trend line has become highly steep beyond 2003 and implies much higher growth rate. The estimated figure for 2006 is 236048 . According to BBS (2006) the number of power tillers in 2005 was 540870 (individually and jointly owned).

\section{Adoption of power tillers and factors affecting adoption}

The number of power tillers in the divisions and density of power tillers in Bangladesh in relation to land area in 2003 are shown in Table 3. The highest number of power tillers was found in Rajshahi division (59123 in number) followed by Dhaka (31471) and Khulna (21059) divisions and the corresponding percentages of the total number of power tillers in those divisions in Bangladesh were 44.4, 23.6 and 15.8, respectively.

Besides, in order to show extent of ownership of power tiller and its intensity in relation to land were as following (i) proportion of total number of power tillers (ii) proportion of farms owning power tillers, (iii) number of power tillers per 1000 persons, (iv) number of power tillers per thousand hectare of (a) irrigated area, (b) gross cropped area, (c) net sown area, and (d) total land area in each division. The adoption of power tillers and relationship with the above criteria are shown in Table 3.

According to the proportion of farms owning PT, among the divisions in Bangladesh the highest adoption of PT was found in Rajshahi (1.9\%) followed by Khulna (1.4\%). On the other hand, the lowest adoption of PT of the total farm household was found in Barisal (0.5\%) followed by Chittagong (0.6).

\section{Results of the multiple regression analysis using division level data}

It was observed in the past that number of power tillers increased and number of bullock power decreased. It was hypothesized that the shortage of draught power may act as a constraint to swift land preparation for crop production and thereby encourage mechanized land preparation, but the significance of the corresponding variable $X_{1}$, is very weak though it bears a minus sign (Table 4). The number of power tillers and the size of population $\left(\mathrm{X}_{5}\right)$ is negatively associated and the coefficient of size of population is significant. The coefficient of the variable representing the extent of small- holdings $\left(\mathrm{X}_{2}\right)$ is positive and statistically significant while the coefficient of landless holdings $\left(\mathrm{X}_{3}\right)$ is negatively significant. This means that extent of small holdings may not be a constraint to mechanization but landless holdings is a constraint because landless farmers have no land and so they do not need power tiller. The coefficients of 
Table 3. Divisionwise power tiller ownership and density of power tillers in relation to land area.

\begin{tabular}{l|l|l|l|l|l|l|l|c}
\hline \multicolumn{1}{c|}{ Divisions } & $\begin{array}{c}\text { No. of } \\
\text { power tillers } \\
\text { in 2003 }\end{array}$ & $\begin{array}{c}\text { \% } \\
\text { PT of the } \\
\text { total } \\
\text { number }\end{array}$ & $\begin{array}{c}\text { Adoption } \\
\text { of PT (\%) } \\
\text { proportion of } \\
\text { farms owning } \\
\text { PT) }\end{array}$ & $\begin{array}{c}\text { PT no. } \\
\text { owned per } \\
1000 \\
\text { popn. }\end{array}$ & $\begin{array}{c}\text { PT no. per } \\
1000 \\
\text { irrigated area } \\
\text { (ha) }\end{array}$ & $\begin{array}{c}\text { PT no.per } \\
1000 \\
\text { cropped } \\
\text { area } \\
\text { (ha) }\end{array}$ & $\begin{array}{c}\text { PT no.per } \\
1000 \text { net } \\
\text { sown area } \\
\text { (ha) }\end{array}$ & $\begin{array}{c}\text { PT } \\
\text { no. per } \\
1000 \text { ha } \\
\text { area }\end{array}$ \\
\hline Barisal & 4822 & 3.6 & 0.5 & 0.6 & 84.4 & 5.1 & 7.7 & 3.6 \\
Chittagong & 11595 & 8.7 & 0.6 & 0.5 & 28.7 & 7.2 & 11.5 & 3.4 \\
Rajshahi & 59123 & 44.4 & 1.9 & 2.0 & 41.5 & 15.8 & 27.2 & 17.1 \\
Dhaka & 31471 & 23.6 & 1.0 & 0.8 & 33.9 & 10.1 & 17.2 & 10.1 \\
Khulna & 21059 & 15.8 & 1.4 & 1.5 & 45.7 & 14.2 & 21.2 & 9.5 \\
Sylhet & 5173 & 3.9 & 0.7 & 0.7 & 25.7 & 7.6 & 9.3 & 4.1 \\
Bangladesh & 133243 & 100.0 & 1.1 & 1.1 & 38.4 & 11.5 & 18.5 & 9.0 \\
\hline
\end{tabular}

Source: Field survey, 2003 and BBS (Various issues)

Note: Adoption of PT (\%) (Proportion of farms owning PT) = Number of PT within the divisision/district multiplied by 100 and dividing by total no. of farm holdings within the division.

PT no.owned per 1000 pop. $=$ PT no. multiplied by 1000 and dividing by the total pop. within the division . 
irrigated area $\left(\mathrm{X}_{4}\right)$, and the credit availability per net cropped area $\left(\mathrm{X}_{6}\right)$, were found positive and statistically highly significant. Thus the two variables, total irrigated area per net cropped area $\left(\mathrm{X}_{4}\right)$ and credit availabilty per net cropped area $\left(\mathrm{X}_{6}\right)$ indicated that the irrigated area, credit availabilty increased the number of power tillers owned by farmers. These variables in the equation accounted for about 69 percent of the variation in the dependent variable (Y). The coefficient of wage rate $\left(\mathrm{X}_{7}\right)$ was positive but not significant. The coefficient of the last variable $\left(\mathrm{X}_{8}\right)$, the relative cost of cultivation by PT was negative and statistically significant and it indicated that lower was the cost of cultivation by PT compared to that by DAP higher would be the extent of adoption.

From the view- point of size of coefficient, $\mathrm{X}_{6}$ was the most effective factor in explaining the number of power tillers. The coefficient of $X_{6}$ reflects that as the credit availability increases, farmers tend to substitute power machine for draught power to increase total cropped area and cropping intensity. Thus the regression analysis indicated that credit availability, irrigated area and small farm holdings affected farm mechanization and the credit availability may be a decisive factor because with the expansion of credit availabilty the number of power tillers increased for land preparation to increase crop production and thus cropping intensity.

Table 4. Coefficients of multiple linear regression model.

$\mathrm{Y}=$ Number of power tillers per net cropped area (NCA)

\begin{tabular}{l|c|c}
\hline \multicolumn{1}{c|}{ Explanatory variables } & Coefficients & t-value \\
\hline Constant & -6.171 & $-2.384^{* *}$ \\
$\mathrm{X}_{1}=$ No. of cattle and buffalo per ha NCA & -0.190 & $-1.465 \mathrm{~ns}$ \\
$\mathrm{X}_{2}=$ No. of Small farm holdings per NCA in ha & 0.334 & $1.875^{*}$ \\
$\mathrm{X}_{3}=$ No. of landless holdings per NCA & -0.796 & $-2.741^{* * *}$ \\
$\mathrm{X}_{4}=$ Total irrigated area /NCA & 0.152 & $1.734^{*}$ \\
$\mathrm{X}_{5}=$ Population per NCA & -0.007510 & $-2.795^{* * *}$ \\
$\mathrm{X}_{6}=$ Credit availability/NCA & 0.773 & $6.799^{* * *}$ \\
$\mathrm{X}_{7}=$ Agricultural wage rate (Taka/day) & 0.919 & $1.497 \mathrm{~ns}$ \\
$\mathrm{X}_{8}=$ Relative cost of cultivation per ha & -3.649 & $-3.475^{* * *}$ \\
$\quad$ (Cost by PT/ cost by DAP) & & \\
$\mathrm{N} \quad$ (no. of observations) & 64 & \\
$\mathrm{~F}$ & $15.620^{* * *}$ & \\
$\mathrm{R}^{2}$ & 0.694 & \\
Adjusted $\mathrm{R}^{2}$ & 0.650 & \\
\hline
\end{tabular}

Source: Field survey 2003 and BBS, various issues.(2001, 2002 and 2005)

Notes: ***,*** indicate significance at 10 percent, 5 percent and 1 percent level, respectively. ns $=$ not significant 


\section{Reasons for purchasing power tiller}

Before studying the diffusion of power tillers in Bangladesh, it is necessary to know the reasons for purchasing PTs and the reasons are shown in Table 5. About 95 percent of the power tiller owners reported that they purchased PT for cultivating their own land. Ninety percent PT owners purchased PT due to shortage of draught power, while 73 percent PT owners reported that they bought PT for timely and faster land preparation. On the other hand, 88 percent PT owners said that they bought PT for own land preparation and for earning money by renting out it to other farmers and for other purposes particularly transportation.

Table 5. Reasons for purchasing power tillers in the study areas.

\begin{tabular}{l|c}
\hline \multicolumn{1}{c|}{ Reasons } & Percentage of respondents \\
\hline a. Shrotage of labour for land preparation & 22 \\
b. Reduce labour cost & 12 \\
c. Easier and faster land preparation & 73 \\
d. Difficult to care for bullocks & 34 \\
e. Bullocks are sold & 10 \\
f. Cultivate own land & 95 \\
g. Rent out/custom work & 88 \\
h. Social prestige & 12 \\
i. Timely planting & 73 \\
j. Better land preparation & 44 \\
k. Reduces drudgery & 51 \\
l. Shortage of draft power & 90 \\
\hline
\end{tabular}

Source: Field survey, 2003

Note: More than one reason were cited by individual respondents

\section{Adoption of power tillers in terms of area at farm level.}

The adoption level of PT mechanization is referred to the percent area under PT to total cultivated area. In Bangladesh the adoption of PT may improve overall efficiency, maximize land and labour productivity, decrease production cost, increase economic returns and decrease inequality among the farmers.

In Table 6, it could be seen that $46.9 \%$ of the net cropped area was under PT fully for land preparation for Boro rice at Rushulpur and Lona site. Similarly, 42.0 and $13.3 \%$ of the total net cropped area was under the use of PT and DAP respectively for Aman rice. In the case of adoption of PT on the basis of total cropped area (Boro+Aman+ Aus+Other crops), it was seen that in $41.2 \%$ of the total cropped area, farmers use PT fully and $13.3 \%$ partially. 
Table 6. Percentage of area cultivated under different land preparation techniques in different locations of the study areas.

\begin{tabular}{|c|c|c|c|c|c|}
\hline Locations/villages & PT & DAP & $\mathrm{PT}+\mathrm{DAP}$ & Tractor & $\begin{array}{c}\text { all (PT+DAP+ } \\
\text { PTDAP+Tractor) }\end{array}$ \\
\hline \multicolumn{6}{|l|}{ Rushulpur and Lona: } \\
\hline Boro & 47 & 14 & 12 & 27 & 100 \\
\hline Aman & 42 & 13 & 10 & 34 & 100 \\
\hline Aus & 34 & 12 & 14 & 40 & 100 \\
\hline Other crops & 30 & 25 & 37 & 9 & 100 \\
\hline Total cropped & 41 & 14 & 13 & 31 & 100 \\
\hline \multicolumn{6}{|l|}{ (Boro+Aman+ } \\
\hline \multicolumn{6}{|l|}{ Aus+other crops) } \\
\hline \multicolumn{6}{|l|}{ Nandigram and } \\
\hline Chakalma: & 82 & 8 & 6 & 5 & 100 \\
\hline Boro & 80 & 9 & 5 & 6 & 100 \\
\hline Aman & 76 & 4 & 15 & 5 & 100 \\
\hline Aus & 60 & 40 & - & - & 100 \\
\hline \multicolumn{6}{|l|}{ Other crops } \\
\hline Total cropped & 80 & 10 & 5 & 5 & 100 \\
\hline \multicolumn{6}{|l|}{ (Boro+Aman+ } \\
\hline \multicolumn{6}{|l|}{ Aus+other crops) } \\
\hline \multicolumn{6}{|l|}{ Shankarchandra and } \\
\hline \multicolumn{6}{|l|}{ Manikdihi: } \\
\hline Boro & 70 & 11 & 15 & 4 & 100 \\
\hline Aman & 71 & 13 & 12 & 4 & 100 \\
\hline Aus & 63 & 18 & 19 & - & 100 \\
\hline Other crops & 68 & 4 & 28 & - & 100 \\
\hline Total cropped & 70 & 11 & 16 & 3 & 100 \\
\hline \multicolumn{6}{|l|}{ (Boro+Aman+ } \\
\hline \multicolumn{6}{|l|}{ Aus+other crops) } \\
\hline \multicolumn{6}{|l|}{ Luxmipur and } \\
\hline Beguntahary: & 82 & 13 & 5 & - & 100.0 \\
\hline Boro & 57 & 30 & 13 & - & 100.0 \\
\hline Aman & - & - & - & - & - \\
\hline Aus & 76 & 16 & 8 & - & 100.0 \\
\hline \multicolumn{6}{|l|}{ Other crops } \\
\hline Total cropped & 71 & 20 & 9 & - & 100.0 \\
\hline \multicolumn{6}{|l|}{ (Boro+Aman+ } \\
\hline \multicolumn{6}{|l|}{ Aus+other crops) } \\
\hline \multicolumn{6}{|l|}{ All locations: } \\
\hline Boro & 74 & 11 & 10 & 7 & 100 \\
\hline Aman & 68 & 14 & 9 & 9 & 100 \\
\hline Aus & 69 & 6 & 14 & 11 & 100 \\
\hline Other crops & 62 & 21 & 16 & 1 & 100 \\
\hline Total cropped & 70 & 12 & 10 & 8 & 100 \\
\hline (Boro+Aman+ & & & & & \\
\hline Aus+other crops) & & & & & \\
\hline
\end{tabular}


At Nandigram and Chakalma site, 81.6 and $8.2 \%$ of the total net cropped area was under PT and DAP, respectively, for Boro rice cultivation. About 80.4 and $8.9 \%$ of total net cropped area were found under PT and DAP for Aman rice cultivation. Considering the three seasons (Boro+Aman+Aus) in a year, the farmers used PT fully in $80.3 \%$ of the total cropped area.

At Shankarchandra and Manikdihi site, $70.0 \%$ of the net cropped area was under Boro rice which was fully tilled using PT. Similarly, 71.3 and $63.1 \%$ of the net cropped area was cultivated fully using PT for Aman and Aus rice respectively. On the whole, considering all the crops grown in a year the area cultivated by PT and DAP at this site was 69.9 and $11.4 \%$ of the total cropped area.

Table 7. Locationwise PT ownership and density of PT in relation to land area at the farm level

\begin{tabular}{|c|c|c|c|c|c|c|c|c|}
\hline $\begin{array}{l}\text { Location/ } \\
\text { Villages }\end{array}$ & $\begin{array}{l}\text { No. of } \\
\text { power } \\
\text { tillers }\end{array}$ & $\begin{array}{c}\% \text { of } \\
\text { PT of } \\
\text { the total } \\
\text { number }\end{array}$ & $\begin{array}{c}\text { Adoption } \\
\text { of PT (\%) } \\
\text { (proportion } \\
\text { of farms } \\
\text { owning PT) }\end{array}$ & $\begin{array}{c}\text { No. of } \\
\text { PT/ } \\
\text { owned/ } \\
1000 \\
\text { popn. }\end{array}$ & $\begin{array}{c}\text { No. of } \\
\text { PT/ } \\
1000 \\
\text { irrigated } \\
\text { area (ha) }\end{array}$ & $\begin{array}{c}\text { No. of } \\
\text { PT/ } \\
1000 \\
\text { cropped } \\
\text { area } \\
\text { (ha) }\end{array}$ & $\begin{array}{c}\text { No. of } \\
\text { PT/ } \\
1000 \\
\text { net } \\
\text { sown ha } \\
\text { area }\end{array}$ & $\begin{array}{c}\text { No. of } \\
\text { PT/ } \\
1000 \text { ha } \\
\text { area }\end{array}$ \\
\hline $\begin{array}{l}\text { Rushulpur and } \\
\text { Lona: Comilla }\end{array}$ & 20 & 17.0 & 9.5 & 11.1 & 400.0 & 142.9 & 377.4 & 363.6 \\
\hline $\begin{array}{l}\text { Nandigram and } \\
\text { Chakalma: } \\
\text { Bogra }\end{array}$ & 52 & 44.1 & 14.6 & 14.9 & 577.8 & 173.3 & 472.7 & 433.3 \\
\hline $\begin{array}{l}\text { Shankarchandra } \\
\text { and Manikdihi: } \\
\text { Chuadanga }\end{array}$ & 24 & 20.3 & 8.6 & 8.0 & 387.1 & 120.0 & 260.9 & 252.6 \\
\hline $\begin{array}{l}\text { Luxmipur and } \\
\text { Beguntahary: } \\
\text { Manikgonj }\end{array}$ & 22 & 18.7 & 7.7 & 7.9 & 488.9 & 146.7 & 314.3 & 303.0 \\
\hline Total & 118 & 100.0 & 10.4 & 10.6 & 477.7 & 149.4 & 363.1 & 344.4 \\
\hline
\end{tabular}

At Luxmipur and Beguntahary site, 82.3, 12.7, and 5.0\% of the total net cropped area was under PT, DAP, and PTDAP, respectively for Boro rice cultivation, while the corresponding figures for Aman rice were 56.8, 30.3 and $13.0 \%$ of the total Aman cropped area. In this site there was no area under Aus rice. Considering all the crops grown in a year, $71.0 \%$ of the total cropped area was cultivated (adoption of PT) using PT.

On an average of all locations, 74.1 and $10.5 \%$ of the total net cropped area was under PT and DAP, respectively, for Boro rice, while for Aman rice, the 
corresponding figures were 68.3 and $13.9 \%$. Considering all the crops grown in a year on an average, 69.6 and $12.2 \%$ of the total cropped area was cultivated using fully PT and DAP respectively.

\section{Ownership and density of PT}

On the basis of the percentage of the total number of PT at the farm level, the highest percentage of PT (44.1) of the total number of the PTs was found at Bogra site followed by Chuadanga site (20.3), while the lowest percentage of PT (17.0\%) was found at Comilla site (Table 7). In terms of the proportion of farms owning PT Bogra site occupied top position followed by Comilla site. The lowest adoption of PT in terms of proportion of farms owning PT of the total farms was found at Chuadanga site followed by Manikgonj site. Density of PT at Comilla site was found higher than that of other sites irrespective of whether density was measured by irrigated area or gross cropped area or land area.

Table 8. Determinants of ownership of PT at farm level.

\begin{tabular}{lc|c|c}
\hline \multicolumn{1}{c|}{ Independent variables } & Coefficients & $\begin{array}{c}\text { Standard } \\
\text { errors }\end{array}$ & Z-statistic \\
\hline Constant & $0.468 \mathrm{~ns}$ & 0.922 & \\
$\mathrm{X}_{1}=$ age of the farmer & $-0.0104 \mathrm{~ns}$ & 0.0224 & \\
$\mathrm{X}_{2}$ = educational level & $0.104^{*}$ & 0.0563 & \\
$\mathrm{X}_{3}=$ adult family members & $-0.464^{* * *}$ & 0.127 & \\
$\mathrm{X}_{4}=$ farm size in ha & $0.263 \mathrm{~ns}$ & 0.281 & \\
$\mathrm{X}_{5}=$ number of DAP owned by & $-0.5226^{*}$ & 0.288 & \\
$\quad$ the farmers & & & \\
$\mathrm{X}_{6}=$ income surplus & $0.000569^{* * *}$ & 0.000109 & \\
$\mathrm{R}^{2}$ (log-likelihood) & 0.43 & & \\
No. of observations & 267 & & \\
\hline
\end{tabular}

Note: *, ** and ${ }^{* * *}$ mean significant at $10 \%, 5 \%$ and $1 \%$ level, respectively.

ns= not significant.

Log of likelihood function -76.580; $\quad$ Restricted log likelihood -134.960

Dependent variables $=$ Ownership of power tiller

(Power tiller owner $=1$, otherwise $=0$ )

\section{Factors affecting the ownership of power tillers at farm level}

Logit model was used to examine the factors influencing the ownership of power tiller at farm level. The estimated coefficients of the logit model of ownership of PT are shown in Table 8. This model is significant at $1 \%$ level on the basis of the 
log likelihood ratio test. This implies that the independent variables taken together influenced the ownership of PT. Age of the farmers $\left(\mathrm{X}_{1}\right)$ does not affect mechanization. Sign of the variable $\left(\mathrm{X}_{1}\right)$ is as expected but the coefficient is insignificant. Educational level $\left(\mathrm{X}_{2}\right)$ significantly and positively affects PT ownership. Similar findings were reported by Bhuiyan (1981), Asaduzzaman (1988), Alam (1995), and Jaim and Rahman (1999). Farm size $\left(X_{3}\right)$ affects ownership of power tillers positively, but the coefficient is insignificant. The number of adult family members $\left(\mathrm{X}_{4}\right)$ and draught power $\left(\mathrm{X}_{5}\right)$ both have significant negative relationship with PT ownership. This means that the less is the number of adult member of family and draught power per farm the higher is the probability of owning a PT. Income surplus $\left(\mathrm{X}_{6}\right)$ has a significant positive relationship with the ownership of PT. The estimated standard errors are asymptotic because of the use of the method of maximum likelihood.

\section{Conclusion}

The number of power tillers and its growth rate unevenly increased in Bangladesh in the past. The proportion of power tillers to the total number of power tillers is the highest in Rajshahi division. The annual growth rate of power tillers is the highest in Dhaka division. There are so many power tillers in some divisions because the lands of those divisions are environmentally more suitable for using power tillers.

Multiple regression analysis revealed that the number of power tillers per unit of net cropped area has an insignificant positive relationship with agricultural wage rate. The extent of landless holdings is found to be a constraint which reduces mechanization significantly. The coefficients of irrigated area, credit availability per net cropped area and wage rate per day indicated that these variables affected farm mechanization and the credit availability may be a decisive factor because with the expansion of credit availability the number of PTs increased for land preparation for multiple cropping to increase total crop production as well as cropping intensity reducing turn-around time and cost.

Ninety five percent of the power tiller owners purchase power tillers for cultivating their own land while 90\% PT owners reported that they purchased PT due to shortage of DAP. The area cultivated under PT is found highest in Boro season followed by Aman season. On an average of all locations, 69.6\% area of the total cropped area is under PT. There is a positive and significant relationship between ownership of PT and educational level and surplus income of farmers. There is a negative and significant relationship between ownership of $\mathrm{PT}$ and number of adult family members and number of draught power. There is a positive but non-significant relationship between ownership of PT and farm size. Thus all these six factors affect the farmers to own PT at farm level. Policy should be taken to distribute PT evenly all over the country. Credit should also be 
given to the poor farmers and owners to buy PT to adopt widely. The identification of the principal constraints or factors promoting wider diffusion of PT innovation may also help formulating policy measures for its rapid and wider adoption to increase food production in Bangladesh.

\section{References}

Abeden, J. 1995. The Structure Conduct and Performance of PT Marketing System in Bangladesh. M.S thesis, Department of Cooperation and Marketing, Bangladesh Agricultural University, Mymensingh.

Alam, S. 1995. Factors Affecting Adoption and Use of Power Tillers in Bangladesh Agriculture- An Economic Study. Bureau of Socio-Economic Research and Training,

Asaduzzaman , M. 1988 Impact of Agricultural Mechanization in Bangladesh. Research Report No. 72, BIDS.

Barton, David. 2000. Options for Farm Power Use in Primary Cultivation on Small Farms: Summary of Main Findings. Journal of Agricultural Machinery and Mechanization. Vol. 4, No. 1. Special Issue on Farm Power Options. The Department of Farm Power and Machinery. Bangladesh Agricultural University, Mymensingh, Bangladesh.

BBS. 1996. Bangladesh Bureau of Statistics Statistical Yearbook of Bangladesh. Statistics Division, Ministry of Planning. Government of the People's Republic of Bangladesh. .

BBS. 2006. Bangladesh Bureau of Statistics Statistical Yearbook of Bangladesh. Statistics Division, Ministry of Planning. Government of the People's Republic of Bangladesh.

Bhuiyan, Md. S, R. 1981. A Study on the Nature of Utilization of Power Tillers vis-à-vis Draft Power in Mymensingh and Jamalpur District.(Unpublished M.Sc.Thesis). Bangladesh Agricultural University.

Dey, Pradip Kumar. 2006. Economic Impact of Power Tiller Mechanization in Bangladesh. Unpublished Dissertation Submitted to Bangladesh Agricultural University, Mymensingh in Partial Fulfillment of the Requirements for the Degree of Doctor of Philosophy in Agricultural Economics. Department of Agricultural Economics, Bangladesh Agricultural University, Mymensingh.

Gill. G.J. 1981. Farm Power in Bangladesh, Vol. 1. University of Reading. Deptt. of Agricultural Economics and Management, U.K

Gujarati, N. Damodar. 2003. Basic Econometrics, Fourth Edition. New York.

Jaim W. M. H. and M. Mizanur Rahman. 1999. Agricultural Mechanization through Private Sector: A Case of Power Tiller for Multiple Uses. Farm Economy Vol. XI. Conference 1999 and Seminar Papers. Transforming Bangladesh Agriculture. Edited by M A Sattar Mandal and Md. Ali Akbar. The Journal of The Bangladesh Agricultural Economists Association. Dhaka-1209. 
Karim, Zahurul. 2009. Science for Food Security. Twenty- First Bangladesh Science Conference. Bangladesh Association for the Advancement of Science (BAAS). Bangladesh agricultural Research Institute, Gazipur, 18 February, 2009.

Kim, Sung-Ho. 1972. A Socio-Economic Analysis of Farm Mechanization in Asiatic Paddy-Farming Societies with Special Reference to Korean and Japanese Cases. Farm Mechanization in East Asia. . Edited by Herman Southworth. The Agricultural Development Council, New York and Singapore.

Krishi Dairy. 2011. Agricultural Information Service. Dhaka, Bangladesh

Ministry of Agriculture (MoA). 2007. Handbook of Agricultural Statistics. Government of the People's Republic of Bangladesh.

Nasirddin, M. 1997. Sustainability and Yield Decline of Modern Rice in Bangladesh, Gazipur, Bangladesh, 1-14.

Quayum, Muhammad Abdul. 2009. Impact of Power Tiller on Crop Output, Employment and Income in Bangladesh. Ph.D Thesis Submitted to the Department of Economics, in Fulfilment of the Requirement for the Degree of Doctor of Philosophy, Jahangirnagar University, Savar, Dhaka.

Rahman, A.K. M. 1999. An Economic Study on Diversified Uses of Power Tillers in a Selected Area of Nilphamari District. M.Sc thesis, Department of Agricultural Economics. Bangladesh Agricultural University, Mymensingh

Rahman, Rushidan Islam. 2002. Determinants of the use of Modern Inputs and Agricultural Productivity in Bangladesh. The Bangladesh Development Studies. Vol. XXVIII, March-June, 2002, Nos. 1 \& 2. pp.77-111.

Sattar, M.A., M.A. Mazed and T. Hossain. 1993. Development and Extension of Agricultural Machinery. Proceedings of the Workshop on Agricultural Mechanization-Its Present Status and Future Strategy in Bangladesh, 25-27 Feb. 1992, Dhaka, BARC. 